\title{
Oral Health Longitudinal Evaluation of Students from a Public School after Guidance and Implementation of Preventive Measures
}

\author{
Avaliação longitudinal da saúde bucal de \\ escolares de escola pública após orientação \\ e realização de medidas preventivas
}

Heleine Maria Chagas RÊGO

Daphne Camara BARCELLOS Letícia Carvalho Coutinho Costa PEROTE

MSM - PhD Student - Institute of Science and Technology, UNESP Univ Estadual Paulista - School of Dentistry - Department of Restorative Dentistry - São José dos Campos - SP - Brazil.

Karina CAVALHEIRO

Undergraduate Student - Institute of Science and Technology, UNESP - Univ Estadual Paulista, School of Dentistry, São José dos Campos - SP - Brazil.

Maria Filomêna Rocha Lima HUHTALA
Sergio Eduardo de Paiva GONÇALVES
Cesar Rogerio PUCCI

$\mathrm{PhD}$ - Professor - Institute of Science and Technology, UNESP - Univ Estadual Paulista, School of Dentistry - Department of Restorative Dentistry São José dos Campos - SP - Brazil.

\section{Abstract}

Objective: To assess longitudinally the DMFT, plaque and gingival rates of children and teenagers from a public school in São José dos Campos, Brazil, after performing a preventive and motivational program through the University Extension program of School of Dentistry of Institute of Science and Technology of São José dos Campos - UNESP. Materials and Methods: 300 students were randomly selected and divided into three groups, Group 1: 100 children from 2nd to 5 th grade of elementary school, Group 2: 100 children from 6th to 9th grade of elementary school; Group 3: 100 teenagers from first to third year of high school. A questionnaire was used to evaluate knowledge about oral habits and general oral health of students. Clinical examinations were performed to assess the gingival, DMFT and plaque index in the initial time $\left(\mathrm{t}_{0}\right), 1$ year $\left(\mathrm{t}_{1}\right)$ and 2 years $\left(\mathrm{t}_{2}\right)$. The questionnaire and clinical examination results led to implementation of a scheme to promote oral health throughout the school years. The collected data were statistically analyzed. Results: Mean values for DMFT were: Group 1: $\mathrm{t}_{0}=2.3 / \mathrm{t}_{1}=2.28 /$ $\mathrm{t}_{2}=1.88$, group 2: $\mathrm{t}_{0}=1.81 / \mathrm{t}_{1}=1.56 / \mathrm{t}_{2}=1.51$ and Group $3: \mathrm{t} 0=1.92 / \mathrm{t}_{1}=2.61 / \mathrm{t}_{2}=1.86$; for dental plaque index: group 1: $\mathrm{t}_{0}=3.83 / \mathrm{t}_{1}=2.62 / \mathrm{t}_{2}=2.30$, group 2: $\mathrm{t}_{0}=2.06$ $/ \mathrm{t}_{1}=3.24 / \mathrm{t}_{2}=1.39$; Group 3: $\mathrm{t}_{0}=2.27 / \mathrm{t}^{1}=0.94 / \mathrm{t}_{2}=$ 0.8 , and the gingival index: group $1: \mathrm{t}_{0}=1.31 / \mathrm{t}_{1}=0.79 /$ $\mathrm{t}_{2}=0.96$, group 2: $\mathrm{t}_{0}=1.27 / \mathrm{t}_{1}=0.84 / \mathrm{t}_{2}=0.38$; group $3: \mathrm{t}_{0}=1.21 / \mathrm{t}_{1}=0.82 / \mathrm{t}_{2}=0.23$. Conclusion: There was $\mathrm{a}$ significant decrease in all evaluated indexes after 2 years of program, confirming thus the importance of systematic implementation of preventive measures.

\section{KeYWORDS}

DMFT; plaque index; gingival index; Oral health.

\section{Resumo}

Objetivo: avaliar longitudinalmente os índices de CPO-D, placa e gengival de crianças e adolescentes de uma escola pública da cidade de São José dos Campos após realização de medidas de prevenção e motivação por meio do programa Extensão Universitária do Curso de Odontologia do Instituto de Ciência e Tecnologia de São José dos Campos - UNESP. Material e Método: foram selecionados aleatoriamente 300 alunos $(\mathrm{N}=300)$, divididos em três grupos distintos; Grupo 1: 100 crianças do $2^{\circ}$ ao $5^{\circ}$ ano do Ensino Fundamental; Grupo 2: 100 crianças do $6^{\circ}$ ao $9^{\circ}$ ano do Ensino Fundamental; Grupo 3: 100 adolescentes do $1^{\circ}$ ao $3^{\circ}$ ano do Ensino Médio. Foi aplicado um questionário para avaliar o conhecimento com relação aos hábitos bucais e conhecimentos gerais sobre a saúde bucal dos alunos. Foram realizados exames clínicos para avaliar o índice gengival, o CPO-D e o índice de placa nos tempos inicial $\left(\mathrm{t}_{0}\right), 1$ ano $\left(\mathrm{t}_{1}\right)$ e 2 anos $\left(\mathrm{t}_{2}\right)$. Os resultados do questionário e dos exames clínicos conduziram à implantação de medidas de promoção de saúde bucal ao longo dos anos letivos. Os dados coletados foram analisados estatisticamente. Resultados: as médias obtidas foram para o índice CPOD: grupo $1, \mathrm{t}_{0}=2.3$ $/ \mathrm{t}_{1}=2.28 / \mathrm{t}_{2}=1.88$; grupo $2, \mathrm{t}_{0}=1.81 / \mathrm{t}_{1}=1.56 / \mathrm{t}_{2}=1.51 \mathrm{e}$ grupo $3, \mathrm{t}_{0}=1.92 / \mathrm{t}_{1}=2,61 / \mathrm{t}_{2}=1,86$; para o índice de placa dental: grupo $1, \mathrm{t}_{0}=3.83 / \mathrm{t}_{1}=2.62 / \mathrm{t}_{2}=2.30$; grupo $2, \mathrm{t}_{0}=2.06$ $/ \mathrm{t}_{1}=3.24 / \mathrm{t}_{2}=1.39$; grupo $3, \mathrm{t}_{0}=2,27 / \mathrm{t}_{1}=0.94 / \mathrm{t}_{2}=0.8$, e para o índice gengival: grupo $1, \mathrm{t}_{0}=1.31 / \mathrm{t}_{1}=0.79 / \mathrm{t}_{2}=0.96$; grupo $2, \mathrm{t}_{0}=1.27 / \mathrm{t}_{1}=0.84 / \mathrm{t}_{2}=0.38$; grupo $3, \mathrm{t}_{0}=1.21 / \mathrm{t}_{1}=0.82$ $/ t_{2}=0.23$. Conclusão: houve redução significante em todos os índices avaliados após 2 anos do programa, constatando-se assim a importância da implantação sistemática de medidas preventivas.

\section{Palavras-chave}

CPO-D; Índice de placa; Índice gengival; Saúde bucal. 
RÊGO HMC et al.

ORAL HEALTH LONGITUDINAL EVALUATION OF STUDENTS FROM A PUBLIC SCHOOL AFTER GUIDANCE AND IMPLEMENTATION OF PREVENTIVE MEASURES

\section{INTRODUCTION}

Despite major achievements associated with oral health in recent decades, many people around the world, especially the poorest, are still affected by dental problems like tooth decay and periodontal disease [1].

A poor oral health can have a serious effect on general health, and many oral diseases are linked to chronic diseases such as diabetes. The experience of pain, problems with food intake, to smile and to communicate, discolored or damaged teeth, have a great impact on people daily life and well-being. Moreover, oral diseases restrict activities at work, home and school. Reports indicate that children with oral health issues are more likely to miss school, leading to more than 50 million school hours lost each year, which affects not only the performance of children in school, but also success in their adult lives [1-3].

It is also important to note that much of these disorders could be prevented by lifestyle changes and sequential reduction of oral health problems [4].

Tooth decay and periodontal disease have historically been considered the most significant oral health problems. Dental caries is still a health issue that affects many industrialized countries, affecting 60 $90 \%$ of schoolchildren and the vast majority of adults, leading to economic and social consequences $[5,6]$.

It is known that in order to the individual to perform their activities properly, one needs a good oral health, being this condition related to socioeconomic and cultural status [7]; therefore it is possible to find the prevalence of oral health problems associated with different habitat and moments [8].

The oral health promotion is part of an expanded concept of health that goes beyond the technical dimension of the dental sector, integrating oral health to other public health practices. This reinforces the need for building healthy public policies, with the development of strategies directed to all people of the community. Health promotion actions also include working with approaches about risk or protective factors for both oral cavity and general diseases (diabetes, hypertension, obesity, trauma and cancer) such as: healthy eating policies to reduce sugar consumption, community approach to increase oral and body hygiene self-care and policy of eliminating smoking and accident reduction [9].

The search for autonomy of citizens is another requirement of health promotion actions. The healthcare team should make a parallel effort to increase autonomy and stimulate self-care practices for patients, families and communities [9].
The school is a place where children spend a big fraction of their lives and acts significantly in shaping the individual. Therefore, it is considered as a reference for the implementation of any program that intends to develop education and awareness of the general public. Most children and teenagers spend four to five hours a day in school. During this time the learning process is established and familiar habits can be influenced [10]. Hence the importance of transmitting directly to the students, information and guidance of oral hygiene since the direct contact between professional and patient prevails all media [11].

According to Traen and Rise [12], the adoption of appropriate oral hygiene habits at student age is critical, especially because such habits, when established in childhood and pre-adolescence, are unlikely to change in adulthood, once it is in this stage that the human being is growing and developing physically and intellectually [13]. Therefore, considerable efforts should be aimed at children, to support them in the adoption of proper oral hygiene habits [12,13].

The epidemiological researches on the prevalence of oral diseases and conditions are essential to support the planning of preventive and care oral health care policies [14].

Considering the presented facts, the objectives of this study were: to assess longitudinally the DMFT, plaque and gingival index of children and teenagers from Elementary and High State School Professora Jeni Davi Pachá of São José dos Campos, SP, Brazil after implementing preventive and motivational measures through the University Extension program of School of Dentistry of Institute of Science and Technology of São José dos Campos - UNESP, in order to promote an excellent oral health standard in a region of low socioeconomic status and limited access to dental services.

\section{Material and Methods}

\section{Ethical aspects}

This study was conducted according to ethical principles, following the guidelines and regulations that govern research involving human beings, according to the resolutions 169/96 of the National Health Counsel. Procedures performed brought no pain, discomfort or risk of any kind to patients, whose responsible was made aware of the purpose of the study and signed the Statement of Informed Consent in proper form. The project was approved by the Ethics Committee of the School of Dentistry of São José dos Campos - UNESP, protocol 038/2008- PH / CEP. 


\section{Sample selection}

From a sample of 780 students of the State School Prof. Jeni Davi Pachá, located in the Buquirinha neighborhood, in São José dos Campos, São Paulo, Brazil, 300 students $(\mathrm{N}=300)$ were randomly selected, according to the following inclusion criteria: both genders, good general health, without neurological disorders. The 300 students were divided into three groups:

Group 1 - included 100 children from the second to fifth year of elementary school;

Group 2 - included 100 children from 6th to 9th grade of elementary school;

Group 3 - included 100 teenagers from first to third year of high school.

\section{Questionnaire}

To assess knowledge in relation to both oral habits and general oral health of the students, a questionnaire was sent to parents to collect data about personal hygiene habits ( 7 questions), feeding (3 questions) and dental history (4 questions), totaling 14 questions. Parents were asked to answer the questionnaires along with their children. The questionnaire is presented in Chart 1.

\section{Chart 1 - Questionnaire}

\begin{tabular}{l}
\hline ORAL HYGIENE: \\
\hline Do how many people live in your household? \\
\hline How many toothbrushes are there in your home? \\
\hline Do you brush your teeth daily? \\
\hline How often do you brush your teeth every day? \\
\hline Do you use dental floss? How many times a day? \\
\hline Do you use toothpaste? \\
\hline Have you already received feeding guidance related to oral \\
health? How (Dentist/ Hygienist, Teacher, Parents, TV/ Radio/ \\
Internet / Magazines)? \\
\hline FEEDING: \\
\hline Do you eat food between meals (Breakfast / lunch / dinner)? \\
\hline Do you ingest sugary foods daily (coffee, juice, soda, sweets, \\
biscuits, chips, chocolate)? \\
\hline Do you have the habit of eating fruits and vegetables daily? \\
\hline DENTAL HISTORY: \\
\hline Have you ever been to the dentist? \\
\hline How long has it been since your last dentist visit? \\
\hline Have you ever received oral hygiene instructions (how to brush \\
and to floss)? \\
\hline By which means (Dentist/ Hygienist, Teacher, Parents, TV/ \\
Radio/ Internet / Magazines)? \\
\hline
\end{tabular}

\section{Clinical examination}

The data were collected by professors, graduate students and undergraduate students who were previously calibrated by a pilot study.

Clinical examinations were performed in the dental office located at the school, in dental chair under the light reflector (Dabi Atlante, Ribeirão Preto, SP, Brazil) using a wooden spatula and previous air drying of oral cavity with air/water spray and cotton rolls. Data were collected regarding the gingival, DMFT and plaque index.

\section{Gingival index}

For the gingival health diagnosis, it was used the gingival index (GI) developed by Löe and Silness [15]. The GI was classified into 04 scores according to the amount of gingival inflammation present:

- Score 0 - Absence of inflammation;

- Score 1 - Mild inflammation: slight color and texture changes in marginal or papillary gingival unity;

- Score 2 - Moderate inflammation: shiny surface, erythema, edema and/or hypertrophy of the marginal or papillary gingival unity;

- Score 3 - Severe inflammation: Intense erythema, edema and/or hypertrophy of the marginal or papillary gingival unit, spontaneous bleeding, ulceration or congestion.

The dental elements received a GI of 0 to 3 (score). The values were summed. Through the sum of divided GIs by the number of evaluated teeth, was obtained the gingival index of each patient. Thus, the IG of the patient is a mean value of examined areas.

\section{DMFT index}

For the DMFT index (index of decayed, missing and filled teeth) was used the methodology originally proposed by Klein and Palmer [16]. The tooth surfaces were dried using the air/water spray and examined teeth were characterized as decayed, missing or filled.

\section{Plaque index}

In order to visualize the plaque index (PI), liquid dye was used, made of basic fuchsin, Replak (De Trey Dentsply GmbH, Konstanz, Germany). Using a microbrush, the solution was applied in all teeth of the students. Then water was provided for rinsing and removing dye excess. The surfaces which remained stained showed the presence of plaque. 
Using the IP developed by Quigley and Hein [17], the buccal and lingual surfaces of the following teeth were evaluated: 16 (55), 36 (75), $12(52), 32$ (72), 21 (61), 46 (85). This IP classified into 6 scores according to the observed amount of visible biofilm. The assigned scores were:

- score 0 = no plaque;

- score 1 = separate spots of plaque at the cervical margin of the tooth;

- score 2 = thin (approximately $1 \mathrm{~mm}$ ) and continuous zone plaque in the cervical margin of the tooth;

- score 3 = plaque zone larger than $1 \mathrm{~mm}$ wide, but not covering more than $1 / 3$ of the tooth crown;

- score $4=$ plaque zone covering more than $1 / 3$ and less than $2 / 3$ of the tooth crown;

- score $5=2 / 3$ or more of the tooth crown covered by plaque.

Through the sum of divided IPs by the number of evaluated teeth was obtained the dental plaque index of each patient. Thus, the IP patient is the average value of the examined areas.

\section{Preventive measures}

The results of clinical examination and questionnaires evaluation led to the implementation of oral health promotion actions throughout the school year. The included actions were:

- Guidance and monitoring of oral hygiene every 6 months, with regular visits from teachers, undergraduates and graduate students of the School of Dentistry of Institute of Science and Technology of São José dos Campos - UNESP;

- Motivation through presentations that stimulated the various age groups separately (plays, films, lectures, interactive discussions);

- Distribution of informative material (leaflets and magazines) about oral health guidance, exposed posters on school to stimulate to maintain oral hygiene and healthy eating;

- Periodic distribution of hygiene kits containing toothbrushes, dental floss and toothpastes.

In the end of the year and again after one year, clinical examination was conducted, collecting the gingival, DMFT and plaque index.

Descriptive analysis was used to assess oral hygiene, diet and history of dental students, through collected data in questionnaires.

For collected data in clinical examination, the indexes were compared for different times through the Wilcoxon nonparametric test [18].

\section{Results}

\section{Questionnaire}

The descriptive statistics results of the questionnaire to assess oral hygiene, diet and dental history of students are described below:

Regarding the results of the question "Do how many people live in your household?" And "How many toothbrushes are there in your house?", $83 \%$ responded that they had the same amount or more toothbrushes than the number of people living in the house, $9 \%$ responded that they had a smaller amount of toothbrushes than the number of people living in the house and $8 \%$ did not answer the question.

Regarding the results of the question "Do you brush your teeth daily?", 97\% responded yes, they do, and 3\% said they do not brush daily.

Regarding the results of the question "How often do you brush your teeth every day?", $63 \%$ responded that they brush their teeth at least 3 times a day, $22 \%$ reported brushing their teeth twice a day, 9\% said they brush their teeth once a day and $6 \%$ did not answer the question.

Regarding the results of the question "Do you use dental floss? How many times a day? “, 33\% said they use dental floss three times a day or more, 23\% said they use dental floss twice a day, $18 \%$ said they use dental floss once a day, $25 \%$ said they do not use dental floss, and $1 \%$ did not answer the question.

Regarding the results of the question "Do you use toothpaste?", 91\% answered that they use toothpaste, $5 \%$ said they do not use toothpaste and $4 \%$ did not answer the question.

Regarding the results of the question "Have you already received feeding guidance related to oral health? How?", 91\% answered" Yes, they had ", $6 \%$ answered" No ", and $3 \%$ did not answer the question; $50 \%$ responded that they had received feeding guidance related to oral health from Dentist/ Hygienist, 19\% from parents, 18\% from teachers, $7 \%$ from media and $6 \%$ did not answer the question.

Regarding the results of the question "Do you eat food between meals Breakfast / lunch / dinner?", 95\% answered "Yes", 4\% answered "No" and 1\% did not answer the question.

Regarding the results of the question "Do you ingest sugary foods daily (coffee, juice, soda, sweets, biscuits, chips, chocolate)?", 96\% answered "Yes", $3 \%$ answered "No" and $1 \%$ did not answer the question.

Regarding the results of the question "Do you have the habit of eating fruits and vegetables daily?", 
$71 \%$ answered "Yes", 21\% answered "No" and 8\% did not answer the question.

Regarding the results of the question "Have you ever been to the dentist?", $94 \%$ answered "Yes", $2 \%$ answered "No" and $4 \%$ did not answer the question.

Regarding the results of the question "How long has it been since your last dentist visit?", 55\% said they had visited the dentist in the last 6 months, 20\% said they had visited the dentist between 6 months and 2 years, 13\% answered they had visited the dentist between 2 and 5 years, $5 \%$ said they had visited the dentist over 5 years ago and $7 \%$ did not answer the question.

Regarding the results of the question "Have you ever received oral hygiene instructions? How?", 93\% answered "Yes", 3\% answered "No" and 4\% did not answer the question. $78 \%$ answered that they received oral hygiene instructions from Dentist/Hygienist, $11 \%$ from parents, $2 \%$ teachers, $3 \%$ from media and $6 \%$ did not answer the question.

\section{Clinical examination}

The mean data of DMFT, plaque and gingival indexes are shown in Tables 1 to 3 .

\section{Table 1 - Mean (standard deviation) of the DMFT INDEX}

\begin{tabular}{c|c|c|c}
\hline GROUP & $\mathbf{t}_{\mathbf{0}}$ & $\mathbf{t}_{\mathbf{1}}$ & $\mathbf{t}_{\mathbf{2}}$ \\
\hline $\mathbf{1}$ & $2.3(2.28)$ & $2.28(2.43)$ & $1.88(2.07)$ \\
\hline $\mathbf{2}$ & $1.81(2.12)$ & $1.56(2.02)$ & $1.51(1.87)$ \\
\hline $\mathbf{3}$ & $1.92(2.0)$ & $2.61(2.24)$ & $1.86(2.22)$ \\
\hline
\end{tabular}

Table 2 - Mean (standard deViation) Of dental PLAQUE INDEX

\begin{tabular}{c|c|c|c}
\hline GROUP & $\mathbf{t}_{\mathbf{0}}$ & $\mathbf{t}_{\mathbf{1}}$ & $\mathrm{t}_{2}$ \\
\hline $\mathbf{1}$ & $3.83(0.92)$ & $2.62(0.86)$ & $2.30(1.32)$ \\
\hline $\mathbf{2}$ & $2.06(1.51)$ & $3.24(1.23)$ & $1.39(1.21)$ \\
\hline $\mathbf{3}$ & $2.27(1.44)$ & $0.94(1.15)$ & $0.89(0.88)$ \\
\hline
\end{tabular}

\section{Table 3 - Mean (standard deviation) of the GINGIVAL INDEX}

\begin{tabular}{r|l|l|l}
\hline GROUP & $\mathbf{t}_{\mathbf{0}}$ & $\mathbf{t}_{\mathbf{1}}$ & $\mathbf{t}_{\mathbf{2}}$ \\
\hline $\mathbf{1}$ & $1.31(0.91)$ & $0.79(0.53)$ & $0.96(1.06)$ \\
\hline $\mathbf{2}$ & $1.27(0.78)$ & $0.84(0.68)$ & $0.38(0.60)$ \\
\hline $\mathbf{3}$ & $1.21(1.0)$ & $0.82(0.62)$ & $0.23(1.21)$ \\
\hline
\end{tabular}

Comparisons between different times were evaluated using Wilcoxon test. $\mathrm{P}$ values $<0.05$ were considered significant. As for the DMFT index, it was observed that groups 1 and 2 showed no statistically significant difference after instituting preventive measures for the initial time, 1 year and 2 years $(p$ $>0.05$ ), while for group 3 , the preventive measures used were effective for times of 1 year and 2 years ( $p$ $<0.05)$.

Regarding the dental plaque index in groups 1,2 and 3, prevention actions employed were effective for the initial period and 1 year $(\mathrm{p}<0.05)$, and the original period and 2 years $(\mathrm{p}<0.05)$. For Group 2, it was also observed that actions were effective for times of 1 to 2 years $(p<0.05)$, but the groups 1 and 3 were not statistically different at this same time interval.

Regarding the gingival index, preventive measures used were effective for groups 1, 2 and 3 compared to the initial time and after 1 year $(\mathrm{p}<0.05)$ and initial and 2 years $(p<0.05)$. For Group 2 , prevention actions used were effective also for times of 1 to 2 years $(p<$ $0.05)$, whereas groups 1 and 3 showed no significant differences after times of 1 to 2 years $(p>0.05)$.

\section{Discussion}

Through a University Extension program sponsored by School of Dentistry of Institute of Science and Technology of São José dos Campos UNESP, during 2 years this study followed students that are placed in a low-income community and with little access to information and oral health care. In addition to promoting the improvement of oral health and diet of the students from the State School "Prof. Jeni Davi Pachá", located in the Buquirinha neighborhood, in São José dos Campos, São Paulo, Brazil, this Extension program stimulated the students to become propagators of this knowledge in the social environment where they live, passing on the information gathered in the school to families and members of the local community, which was considered of major importance in this project.

Besides improving the oral health of these public school students, this study aimed to: promote a link among undergraduate students, graduate students and professors from the Institute of Science and Technology of São José dos Campos - UNESP - School of Dentistry with the reality of the city's communities; encouraging the extension with prevention methods and to search a method that can be applied to other groups.

All activities were carried out in order to achieve 
a good standard of oral health in the population and to train students and teachers as multipliers of this information, transferring the knowledge gained to the household.

Regarding the results obtained by the questionnaire, it can be observed that the studied population had knowledge of oral hygiene, but with some shortcomings. It was found that in some families the number of toothbrushes in the house was smaller than the number of inhabitants. It was also observed that $97 \%$ of the students brushed their teeth every day; however, only $63 \%$ performed brushing three times per day or more. A relatively low number of students (5\%) did not use toothpaste; however, $25 \%$ of students did not use dental floss. To solve these problems, kits containing toothbrushes, dental floss and toothpaste were regularly donated, and after distribution, lectures were held for oral hygiene guidance and motivation. Oliveira et al. [19] reported the importance of motivation for children to promote improvements in daily oral hygiene habits, and that brushing three times a day is very important in prevention of oral diseases, once it acts as a daily topical fluoride application $[20,21]$ just as the use of dental floss for removing dental plaque from interproximal areas [22].

Different motivational strategies were used for different age groups, trying to make the learning process enjoyable. This is because, according to Rantichieri [23], motivation of children during the educational process involves the use of various activities and resources because they react differently to different worked stimulus. It also highlights the importance of recreation as a facilitator of this process. When using games, children improve their knowledge of the surrounding world, creating meaning, assimilating social roles, the understanding of emotional relationships and the building of knowledge. The use of games, plays and art provides moments and exchange of experiences, creating conflicts, reframing what they live and feel, to then assimilate knowledge.

Regarding to feeding, the questionnaires' results showed that $95 \%$ of students eat food between meals, $96 \%$ eat sugars daily and only $71 \%$ eat fruits and vegetables daily. The high sugar consumption is associated with high prevalence of dental caries, thus increasing the DMFT index of the population [24]. Besides the regular tooth brushing, there must be changes in infant feeding habits in order to promote oral health. Therefore, preventive measures to reverse these results were dietary counseling for prevention and maintenance of oral health, lectures on proper nutrition and rational use of sugars, as well as posters displayed at school to promote a healthy diet, so that such dietary habits may be acquired in childhood and maintained in the future as dietary pattern $[25,26]$.

Regarding the dental history of students, 94\% have visited the dentist, $55 \%$ in the last 6 months, $20 \%$ between 6 months and 2 years and $18 \%$ at least 2 years ago. Furthermore, $93 \%$ of students have received oral hygiene orientation, $78 \%$ from hygienists/ dentists. Regular visits to the dentist have fundamental importance because it can be an indicator of oral and general health of the patient [27]. Macek et al. (2005) [28] observed that children who visited the dentist and underwent prophylactic procedures in the last 12 months had better oral health. During the visit to the dentist, oral hygiene orientation occurs, which encourages patients to improve oral hygiene, though for a short period of time [29]. Therefore, the lectures also aimed to encourage students to make regular visits to the dentist as a preventive measure for reduction of plaque and DMFT index.

After one year, an increase in DMFT index was observed in group 3 and in plaque index in group 2, although the other indexes have decreased. According to Adeniyi et al. [4], despite the offered guidance, issues such as high cost of dental treatment, low understanding of oral health, oral health lowest priority before other needs, such as nutrition, can interfere with the oral health maintenance in the low income population. Therefore, these results led to a change in strategy with repeated instructions and motivations for these groups in the following year, aiming to achieve sustainable changes in behavior, and accordingly in the results of the evaluated indexes.

Such changes in strategies had positive results, because a decrease in DMFT index of group 3 and plaque index in group 2. These results corroborate the findings by Toassi and Petry [30], who concluded that motivation in educational-preventive programs has great importance in the reduction and control of gingival bleeding and dental biofilm index, being much more effective if accompanied by continued reinforcement sessions.

A significant decrease was observed in plaque index for all groups after two years of evaluation. These results agreed with by Schaeken et al. [31], which observed that the use of mechanical devices such as toothbrushes and dental floss is the most effective method to maintain free of plaque tooth surfaces, being therefore critical for the dental caries control. These findings also agree with those found by Garcia et al. [32] and Toassi and Petri [30], which observed a 
significant decrease in plaque index of students after the application of an oral health instruction method. Leal et al. [33] also observed a decrease in plaque index in kindergarten children in Brasilia, Brazil, after application of three different methods of instruction and reinforcement. Just as in the study of Costa [34], with visually impaired children who received oral hygiene instructions, also observing reduction in plaque and gingival bleeding indexes.

A significant decrease of gingival index was observed for all groups, by comparing the beginning and the end of the first year of evaluation of the Extension program. Therefore, preventive and motivational measures were maintained in the Extension program, and through 2 years of evaluation, all groups showed a significant reduction in gingival index for 2 years from the initial time.

Stoner and Prophet [35] observed that there is a correlation between the plaque presence and gingival inflammation, concluding that poor oral hygiene is the gingivitis etiological factor. Thus, gingival index reflects the oral hygiene condition obtained by brushing frequency in a population, as noted in the results of this study, which showed a significant decrease after 2 years of evaluation in both plaque and gingival indexes of students.

The results showed high standard deviation values. This fact is due to polarization of oral diseases in this study, with a large number of individuals with disease absence, or very low rates, and a small number of individuals concentrating high disease rates [36, 37]. This polarization may be related to: the high cost of dental care and oral health lowest priority before other needs in this low-income population. Individuals in this context are the so-called high-risk groups, which end up concentrating the highest levels of tooth decay and thereby polarizing the disease distribution.

Although the oral health knowledge alone does not guarantee a lasting change in behavior, this is an important factor to encourage the incorporation of healthy habits in life $[36,37]$. Thus, it is stimulated the need to put educational guidelines in curriculum

\section{References}

1. Peterson PE. The World Oral Health Report 2003: continuous improvement of oral health in the 21 st century - the approach of the WHO Global Oral Programme. Community Dent Oral Epidemiol. 2003;31(1):3-23.

2. Gift HC, Reisine ST, Larach DC. The social impact of dental problems and visits. Am J Public Health. 1992;82(12):16638.

3. World Health Organization. Oral Health Promotion: an of schools, pointing that educational and preventive measures aimed at improving oral health can and should be developed [38].

As stated earlier, the majority of children and teenagers spends four to five hours a day in school; period in which the learning process is established and familiar habits can be influenced [10]. Accordingly, it is really important to work with this group, because in this stage is possible to create new habits and to change existing ones. It should also be considered that these children start to act as propagators of such knowledge within the community reality where they are, and often are the only information source, because it is a poor community, where the population has little access not only to information but also to oral health treatment.

Couto et al. [39] conducted a thorough review of accomplished researches on educational resources and programs aimed at motivating / education for prevention of periodontal disease and caries, noting that the dental literature shows that the direct motivation is the most effective way to modify the patient behavior and take him/her to exercise satisfactory biofilm control. The data found in this study corroborate these authors because, as the activities were conducted at school, there was an improvement in oral health indexes of the students.

However, it is important to continue the extension program for a period exceeding two years to achieve significant reduction in DMFT indexes for groups 1 and 2, showing the need of continued monitoring of these individuals. Therefore, it is necessary to foster Extension programs in Universities aiming to train participatory students and professors in poor communities, improving the quality of life of the population.

\section{Conclusion}

It can be concluded that employed actions in this study achieved its purpose, promoting a decrease in the gingival, DMTF and plaque indexes. essential element of a health-promoting school: document eleven. Geneva: WHO; 2003.

4. Adeniyia AA, Agbajeb O, Onigbindec O, Ashiwajud O, Ogunbanjoe O, Orebanjof O, et al. Prevalence and pattern of dental caries among a sample of Nigerian public primary school children. Oral Health Prev Dent. 2012;10(3):267-74.

5. Peterson PE, Bourgeois D, Ogawa H, Estupinan-Day S, Ndiaye C. The global burden of oral diseases and risks to oral health. Bull World Health Organ. 2005;83(9):661-9.

6. Perin PCP, Garbin AJI, Perin LFMG, Pereira MA, Abreu 
KCS. Percepção e condição de saúde bucal em crianças numa Instituição na cidade de Lins/SP. Rev Fac Odontol Lins. 2004;16(2):33-8.

7. Pauleto ARC, Toralles P, Cyrino EG. Saúde bucal: uma revisão crítica sobre programações educativas para escolares. Ciênc Saúde Coletiva. 2004;9(1):121-30.

8. Smyth E, Caamaño F. Factors related to dental health in 12 -year-old children:a cross-sectional study in pupils. Gac Sanit. 2005;19(2):113-9.

9. Brasil, Ministério da Saúde. Diretrizes da política nacional de saúde bucal; 2004.

10. Burghardt JA, Devaney BL, Gordon AR. The school nutrition dietary assessment study: summary and discussion. Am J Clin Nutr. 1995;61(1Suppl):252S-7S.

11. Souza LZ. Avaliação de um programa educativo direcionado a crianças com alto risco à carie [tese]. Piracicaba(SP): Faculdade de Odontologia de Piracicaba, UNICAMP Universidade Estadual de Campinas; 2004.

12. Traeen B, Rise J. Dental health behaviours in a Norwegian population. Community Dent Health.1990;7(1):59-68.

13. Figueira TR, Leite ICG. Percepções, conhecimentos e práticas em saúde bucal de escolares. RGO. 2008;56(1):2732.

14. Gesser HC, Peres MA, Marcenes W. Condições gengivais e periodontais associadas a fatores socioeconômicos. Rev Saúde Pública. 2001;35(3):289-93.

15. Löe H, Silness J. Periodontal disease in pregnancy. I. Prevalence and severity. Acta Odontol Scand. 1963;21(6):533-51

16. Klein H, Palmer CE. Dental caries in American Indian children. Public Health Bull. 1937;239:1-53.

17. Quigley GA, Hein JW. Comparative cleansing efficiency of manual and power brushing. J Am Dent Assoc. 1962;65:269.

18. Daniel WW. Biostatistics: a foundation for analysis in the health sciences. 6th ed. New York: John Wiley \& Sons; 1995.

19. Oliveira GCR, Gauch AL, Machado MAAM, Abdo RCC. Higiene bucal orientada: avaliação da influência da escovação, na condição gengival de crianças fissuradas de lábio e/ou palato. RGO. 1992;40(6):388-92.

20. Maltz M, Carvalho J. Tratamento da doença cárie. In: Kriger L. (Org.). Promoção de saúde bucal. São Paulo: Artes Médicas; 1997.

21. Naressi WG, Moreira EJG. Odontologia preventiva: agentes mecânicos de higiene bucal. RGO.1982;30(2):154-6.

22. Pereira AA, Sundefeld MLMM, Arcieri RM, Garbin CAS, Moimaz SAS, Saliba NA. Avaliação do programa de educação em saúde bucal da Faculdade de Odontologia de Araçatuba. Rev Paul Odont. 2005;27(3):28-31.

23. Rantichieri ACT. O lúdico e o processo de ensinoaprendizagem [monografia]. Campinas(SP): UNICAMP Universidade Estadual de Campinas; 2006.

24. Newbrun E. Dental caries in the future: a global view. Proc Finn Dent Soc. 1992;88(3):155-61.

25. Tashima AY, Verrastro AP, Ferreira SLM, Wanderley MT. Correlação entre o aconselhamento dietético-nutricional e a promoção de saúde na clínica de odontopediatria. JBP, J Bras Odontopediatr Odontol Bebê. 2000;3(16):505-12.

26. Campos JADB, Zuanon ACC, Campos AG. Influência da alimentação e da nutrição na odontogênese e desenvolvimento de lesões de cárie dental. JBP, J Bras Odontopediatr Odontol Bebê. 2003;6(31):246-9.

27. Kirkevang LL, Wenzel A. Risk indicators for apical periodontitis. Community Dent Oral Epidemiol. 2003;31(1):59-67.

28. Macek MD, Wagner ML, Goodman HS, Manz MC, Marrazzo ID. Dental visits and access to dental care among Maryland schoolchildren. J Am Dent Assoc. 2005;136(4):524-33.

29. Kay E, Locker D. A systematic review of the effectiveness of health promotion aimed at improving oral health. Community Dent Health. 1998;15(3):132-44.

30. Toassi RFC, Petry PC. Motivação no controle do biofilme dental e sangramento gengival em escolares. Rev Saúde Pública. 2002;36(5):634-7.

31. Schaeken MJ, Creugers TJ, Van der Hoeven JS. Relationship between dental plaque indices and bacteria in dental plaque and those in saliva. J Dent Res. 1987 Sep;66(9):1499-502.

32. Garcia PPNS, Nogueira I, Dovigo LN, Dotta EAV, Dovigo MRPN, Nassour EISC, et al. Educação em saúde: efeito de um método de auto-instrução sobre os níveis de higiene oral em escolares. Pesq Bras Odontoped Clin Integr. 2009;9(3):333-7.

33. Leal SC, Bezerra ACB, Toledo OA. Avaliação da eficácia do ensinamento de métodos de escovação dentária em crianças pré-escolares. Braz Dent J. 2002;13(2):133-6.

34. Costa FS, Neves LB, Bonow MLM, Azevedo MS, Schardosim LR. Efetividade de uma estratégia educacional em saúde bucal aplicada a crianças deficientes visuais. RFO UPF. 2012;17(1):12-7.

35. Stoner JE, Prophet AS. Early periodontal disease in children and young adults. Dent pract. 1970 Jan;20(5):173-6.

36. Biesbrock AR, Walters PA, Bartizek RD. Initial impact of a national dental education program on the oral health and dental knowledge ofchildren. J Contemp Dent Pract. 2003;4(2):1-10.

37. Mayer MP, Paiva Buichi Y, Oliveira LB, Gjermo O. Longterm effect of oral hygiene training program on knowledge and reported behavior. Oral Health Prev Dent. 2003;1(1):3743.

38. Chaves RA, Neves AM, Miranda KCO, Passos IA, Oliveira AFB. Consultório odontológico na escola: análise da saúde gengival e do nível de higiene oral. RGO. 2011;59(1):29-34.

39. Couto JL, Couto RS, Duarte CA. Motivação do paciente. RGO. 1992;40(2):143-50.

Received: 2012-12-13

Accepted: 2013-03-02

\section{Corresponding Author}

Heleine Maria Chagas Rêgo

Department of Restorative Dentistry - São José dos Campos School of Dentistry - UNESP Univ. Estadual Paulista - São José dos Campos - Brazil.

Av. Eng. Francisco José Longo, 777, Jd. São Dimas, São José dos Campos, SP, CEP:12245-000, Brasil. email: heleine_rego@hotmail.com 